\title{
Rock Slope Stability Assessment of Limestone Hills in Northern Kinta Valley, Ipoh, Perak, Malaysia
}

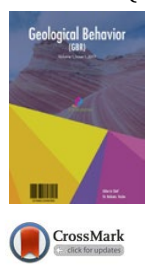

\author{
GOH THIAN LAI1*, , AINUL MARDHIYAH MOHD RAZIB1,NUR AMANINA MAZLAN1, ABDUL GHANI RAFEK2, AILIE SOFYIANA SEK̄Ā̄̄Ā̄, İŪK̄BERT \\ SIMON1, NORAINI SURIP3, LEE KHAI ERN4AND TUAN RUSLI MOHAMED5 \\ 1School of Environmental and Natural Resource Sciences, Faculty of Science and Technology, Universiti Kebangsaan Malaysia, 43600 UKM Bangi, Selangor \\ Darul Ehsan, Malaysia \\ 2Department of Geosciences, UniversitiTeknologi PETRONAS, Bandar Seri Iskandar, 31750 Tronoh, Perak DarulRidzuan, Malaysia \\ 3Chemical and Petroleum Engineering Department, Faculty of Engineering, Technology and Built Environment, UCSI University, 56000 Cheras, Malaysia \\ 4Institute for Environment and Development (LESTARI), UniversitiKebangsaan Malaysia, 43600 UKM Bangi, Selangor, Malaysia. \\ 5Department of Mineral and Geoscience Malaysia Perak, Jalan Sultan Azlan Shah, 31400 Ipoh, Perak, Malaysia \\ *Corresponding author: gdsbgoh@gmail.com
}

This is an open access article distributed under the Creative Commons Attribution License, which permits unrestricted use, distribution, and reproduction in any medium, provided the original work is properly cited

\section{ARTICLE DETAILS}

Article history:

Received 27 September 2016 Accepted 13 December 2016 Available online 10 January 2017

Keywords:

Limestone, failure modes, rock slope stability assessment

\section{ABSTRACT}

The uniqueness of karsttopography in Kinta Valley lies with the spectacular shape of the steep-sided limestone towers. However, theinstability ofthese hillslopes may affect the vulnerability of the surrounding area. Thus, this study was conducted with the objective to investigate the failure modes of 9 slopes in the vicinity ofnorthernKinta Valley, Ipoh, Perak. There were two types of failure modes identified in the study area,which are planar and wedge failures. Planar failures were identified on slope GL3of Gunung Lang and slope GR3of Gunung Rapat with the dip direction and dip angle of $280^{\circ} / 79^{\circ}$ and $004^{\circ} / 64^{\circ}$ respectively. Two wedge failures were identified on slope QXL1 of Qing Xing Ling, Taman Saikat with dip direction and dip angle of $252^{0} / 82^{\circ}$ and $302^{\circ} / 74^{0}$ respectively. A wedge failure was identified on slope GL3 for Gunung Lang, slope GR1, slope GR3 for Gunung Rapat and slope QXL2 for Qing Xing Ling,Taman Saikat. The dip direction and dip angle for the respective wedges failure were $345^{\circ} / 65^{\circ}$, $036^{\circ} / 49^{\circ}, 006^{\circ} / 64^{\circ}$ and $025^{\circ} / 60^{\circ}$. No failure was identified on slope GL1, and slope GL2,forGunung Lang and slope GR2, and slope GR4forGunungRapat.

\section{INTRODUCTION}

Karst topography in Kinta Valley is characterised by the steep- sided limestone hills and decorated with many limestone morphological features such as caves and dolines. Kinta Valley has been proposed to be developed as one of the national geoparks in Malaysia due to its impressive beautiful landscape (Leman, 2013).A literature study revealed that less research studies have been conducted on limestone hill's rock slope stability assessment. The local researchers were focused more on rock mass classification (Norbert et al. 2016), landslide (Norbert et al. 2013,Norbert et al. 2014, Norbert et al. 2015a), rock fall (Norbert et al. 2015b) and prediction of uniaxial compressive strength using ultrasonic (Goh et al. 2016, Goh et al. 2015a, Goh et al. 2015b, Goh et al. 2014b). Ghani Rafek et al. (2012), Ghani et al. (2011) and Goh et al. (2012a, 2014a) characterized the roughness of discontinuities surface by established a polynomial relationship between JRC with peak friction angles schist and granite. Goh et al. (2012b) investigated the influenced of conditions of weathering to the Geomechanical strength of Granites and Schists. Abdul Ghani Rafek et al. (2015) assessed the Kinta limestone based on slope mass rating. Geohazard incidents like rock slab detachment and rock falls might occur as a result of weathering processes and discontinuity factors characterised mainly by geological structure conditions such as jointing, fractures and daylighting of discontinuities.These geological hazards will affect the vulnerability of development in the encompassing areas(Shu \& Lai, 1974). The impact of a rockfall can also affects its surrounding in which the air blast resulting from the fallen rock debris can be felt at a distance that is much further from the catastrophe area which could affect nearby buildings (Lai, 1974, Shu \& Lai, 1974).

As stated by Shu and Lai (1973), reports on the instability of limestone hills such as at Gunung Cheroh in the Kinta Valley have been a subject of investigations by the Geological Survey of Malaysia in early1927. One of the incidents of rockfall tragedy had occurred at Gunung Cheroh, Ipoh, Perak which caused the demise of 40 people in October, 1973 (Shu \& Lai 1974). Rock fall incident at Gunung Pondok, Perak were also reported by Shu and Razak (1984).

Structural failure has been reported as the main causal factor of the rockfall events. Chemical weathering process also contributes to the decomposition of the rock mass.According to Chow and Sahat (1988) chemical weathering from water dissolution and quarry activities were reported to be the main causal factors of rockfalls such as the incident which occurred at Gunung
Tunggal. It was reported that the cohesive strength along joints and fractures had decreased due to chemical weathering which possibly caused the rockfall.

With regard to these issues, this research was conducted to investigate the failure modes of eight limestone hills in the Kinta Valley by using kinematic analysis as recommended by Hoek and Bray (1981). The examples of rockfall events in the Kinta Valley that had caused a number of fatality and damages to vehicles and civil structures are shown in Table 1.

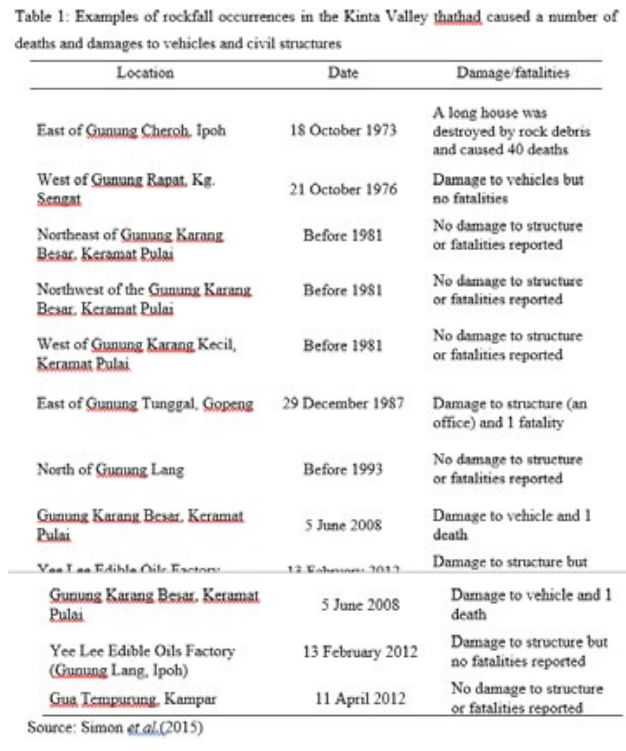

MATERIALS AND METHODOLOGY

Geology of Study Areas

The study area is located in the Kinta Valley, Perak as shown in Figure 1. The study areas covered the massive limestone bodies that are heavily jointed and fractured. As stated by Simon et al. (2015), there arenumerous massive limestone hills with an average size of 1.08 
$\mathrm{km} 2$ with maximum elevation of these hills reaching $546 \mathrm{~m}$ based on the topographic map.The localized, highly weathered schist was found at the bottom of a massive limestone bodywhich can be observed in a cave located at Gunung Rapat. This limestone bodies were named by Foo (1983) as Kinta Limestone Formation with age of Silurian to Permian.

\section{Methodology}

Discontinuity surveys wereconducted by using the scan line method as suggested by Priest and Hudson (1976) and ISRM (1978) where 10 discontinuity parameters were considered. The parameters are dip direction, dip angle, discontinuity length (persistence), aperture, surface roughness, infilling, weathering, groundwater conditions, number of joint sets and block size.

The kinematic analysis was conducted by using Stereo32 software (Ruhr University Bochum, 2016). The results were interpreted to identify types of failure mode based on Hoek and Bray (1981). According to them, the possible major types of block failures on slopes and structural geology conditionsare plane failure, wedge failure, toppling failure and circular failure.The joint roughness coefficient values were used for the determination of peak friction angle as recommended by Ghani Rafek et al. (2012).

\section{RESULTS AND DISCUSSION}

A total of 9 slopes at the Northern Kinta Valley were assessed and labeled as GL1, GL2, and GL3 for Gunung Lang, GR1, GR2, GR3 and GR4 for Gunung Rapat and QXL1 and QXL2 for Qing Xing Ling, Taman Saikat as shown in Figure 3, Figure 4, Figure 5, Figure 6, Figure 7, Figure 8, Figure 9, Figure 10 and Figure 11, respectively. The locations of respective slopes are shown in Figure 2. The stereographs of respective slope were shown in Figure 12, Figure 13, Figure 14, Figure 15, Figure 16, Figure 17, Figure 18, Figure 19 and Figure 20, respectively. GL1, GL2, and GL3of Gunung Lang are composed of 5 major joint sets. GR1, GR2, GR3 and GR4 for Gunung Rapat were composed of 4 major joint sets. 4 major joint sets were identified on slope QXL1 and QXL2 for Qing Xing Ling, Taman Saikat. The orientation of major joint sets and slope face of the respective slope are shown in Table 2.

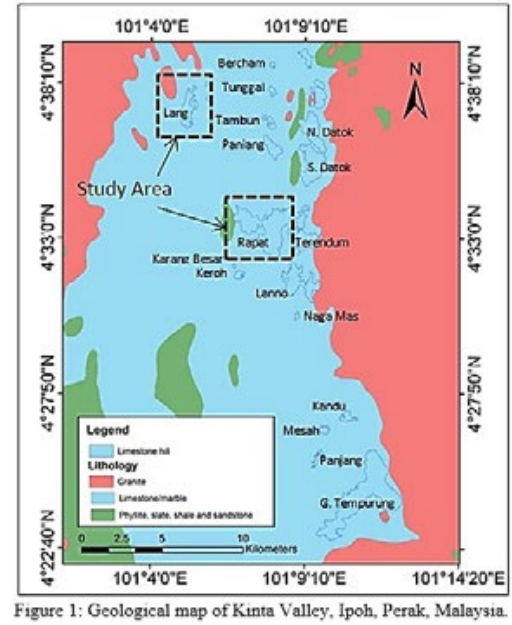

Source: Modified from Norbert et al. (2015b)

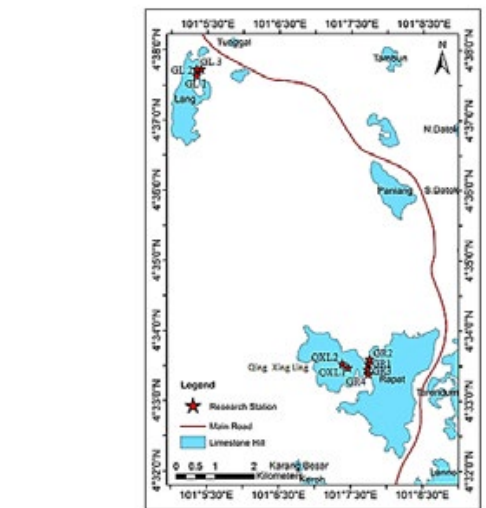

Figure 2: Location map for 9 slopes of study areas in the Northen Kinta Valley, Ipoh, Perak, Malaysia
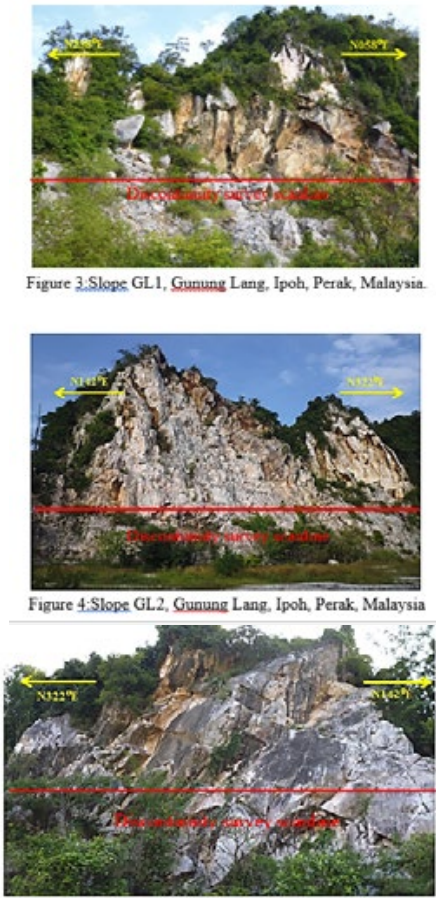

Figure 5: Slope GL3, Gunung Lang, Ipoh, Perak, Malaysia

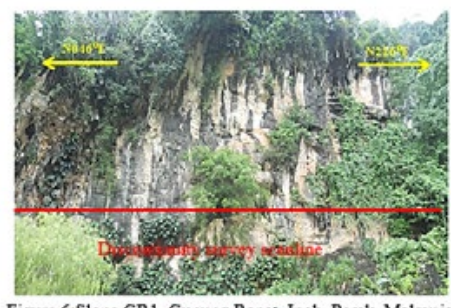

Figure 6:Slope GR1, Gunung Rapat, Ipoh, Perak, Malaysia

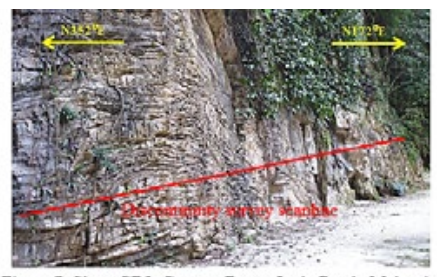

Figure 7: Slope GR2, Guming Rapat Ipoh, Perak, Malaysia

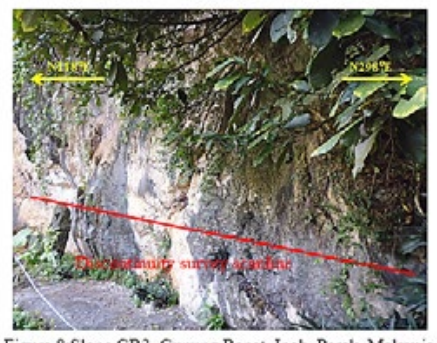

Figure 8. Slope GR3, Gumung Rapat. Ipoh, Perak, Malaysia
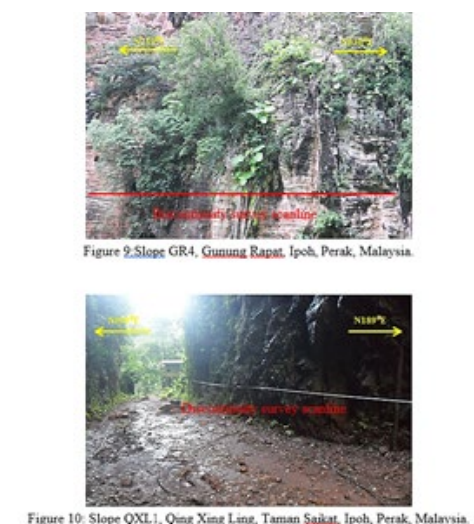


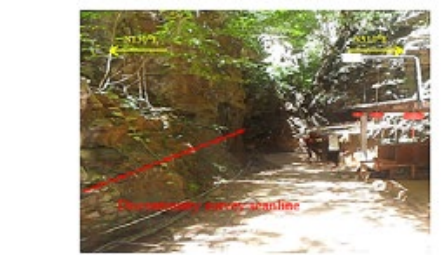

Figure 11: Slope QXL2, Qing Xing Ling, Taman Saikat. lpoh, Perak, Malaysia

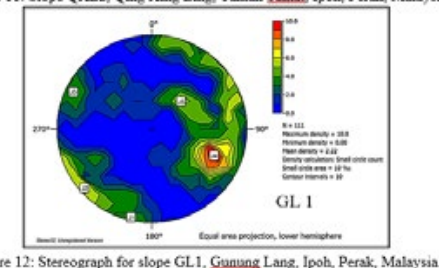

Figure 12: Stereograph for slope GL1, Gunung Lang, Ipoh, Perak, Malaysia.
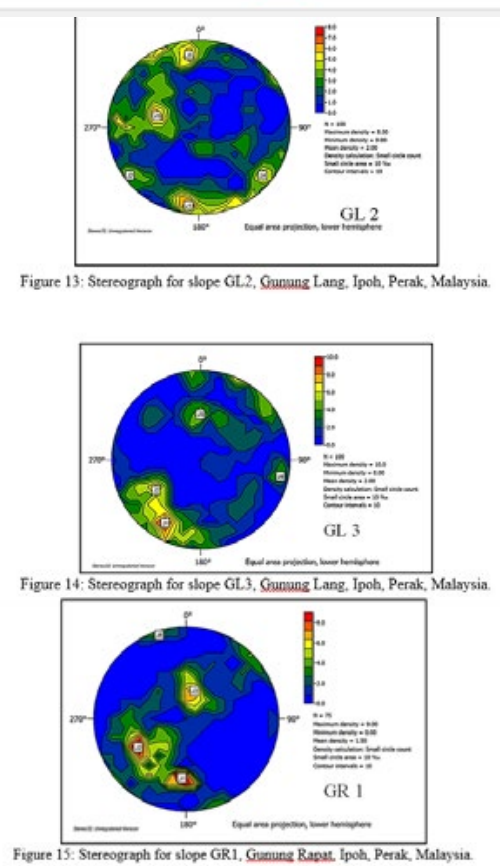

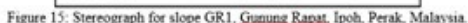
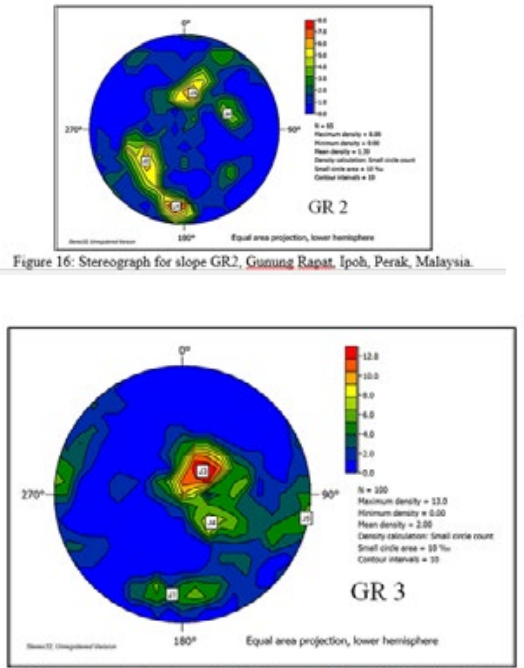

Figure 17: Stercograph for slope GR3, Gunung Rapat, Ipoh, Perak, Malaysia.

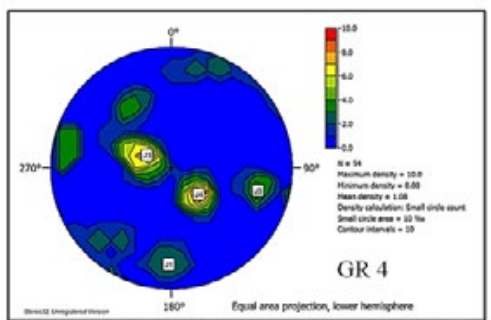

Figure 18: Stereograph for slope GR4, Gunung Rapat, Ipoh, Perak, Malaysia.

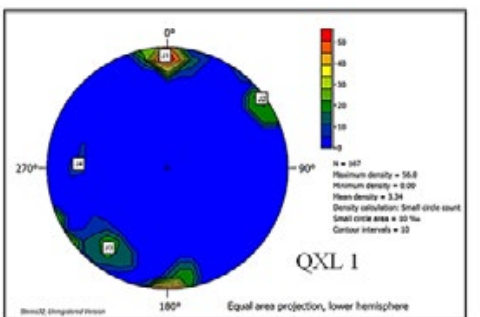

Figure 19: Stereograph for slope QXI.1, Qing Xing Ling, Taman Saikat. Ipoh, Perak, Malaysia

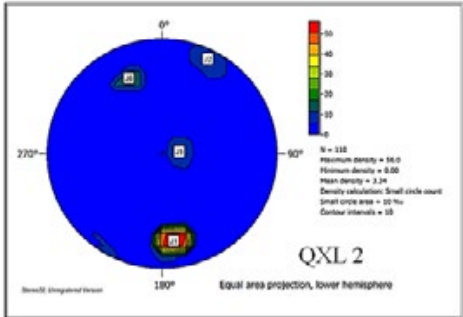

Figure 20: Stereograph for slope QXL2, Qing Xing Ling, Taman Sakat, Ipoh, Perak, Malavsia

Table 2. Orientation of major joint set and slope face for slopes GL1, GL2 and GL3, for Gunung Lang, Ipoh; GR1, GR2, GR3 and GR4, for Gunung Rapat, Ipoh; QXI1 and QXI2, for Qing Xing Ling, Taman Saikat. Ipoh, Perak, Malaysia.

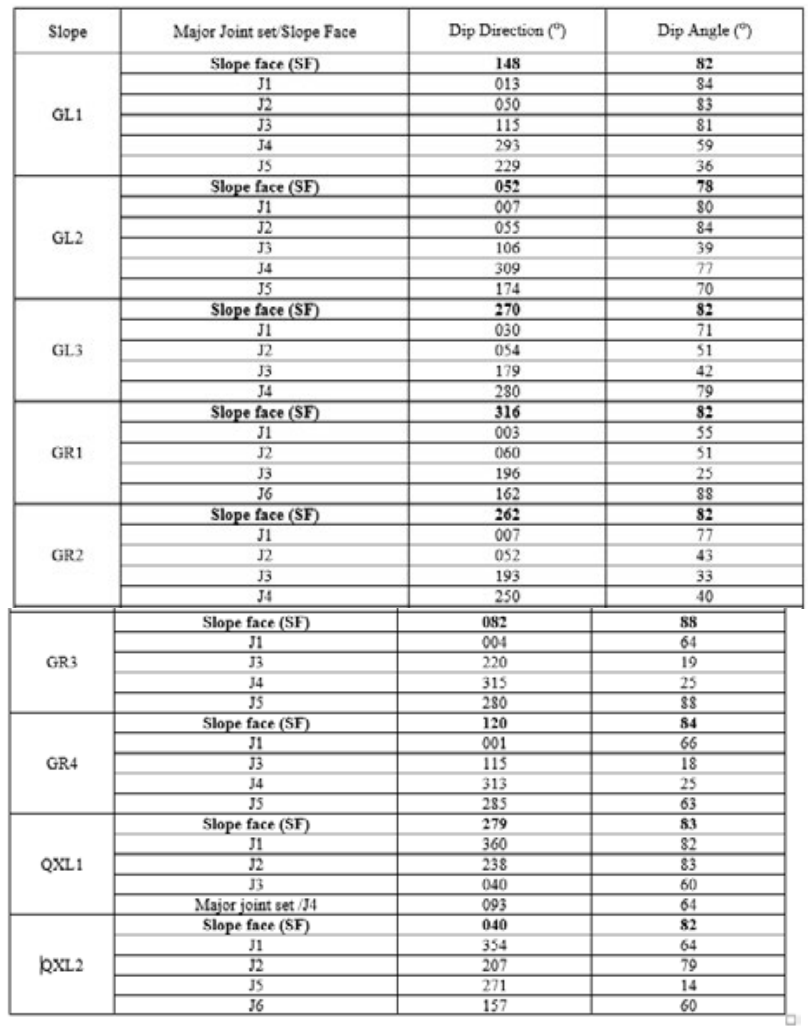

The peak friction angles for respective slopes used in kinematic analysis were determined based on the tilt test method suggested by Abdul Ghani Rafek and Goh (2012). The peak friction angle for slope GL1, GL2, and GL3 for Gunung Lang was $43^{\circ}$. The peak friction angles for slope GR1, GR2, GR3 and GR4 for Gunung Rapat were $43^{\circ}, 70^{\circ}, 33^{\circ}$ and $49^{\circ}$ respectively. The peak friction angle for slope QXL1 and QXL2 for Qing Xing Ling was $49^{\circ}$.

Figure 21, Figure 22, Figure 23, Figure 24, Figure 25, Figure 26, Figure 27, Figure 28 and Figure 29 shows the results of kinematic analysis for respective slopes. Table 3 shows the summary of kinematic analysis for the respective slopes. Wedge and planar failures were identified on slope GL3 for Gunung Lang. The dip direction/dip angle for respective wedge and planar failures were $345^{\circ} / 65^{\circ}$ and $280^{\circ} / 79^{\circ}$. No mode of failure was identified on slope GL1 and GL2 for Gunung Lang. 
A wedge failure was identified on slope GR1 with the respective dip direction/ dip angle of $036^{\circ} / 49^{\circ}$.A wedge failure and planar failure was identified on slope GR3 for Gunung Rapat with the respective dip direction/ dip angle of $004^{\circ} / 64^{\circ}$ and $006^{\circ} / 64$. No mode of failure was identified on slope GR2 and GR4 for Gunung Rapat. There were two wedge failures identified on slope QXL1 and one wedge failure on slope QXL2 for Qing Xing Ling, Taman Saikat. The respective dip direction/dip angle of wedge failures were $252^{\circ} / 82^{\circ}, 302^{\circ} / 74^{\circ}$ and $025^{\circ} / 60^{\circ}$.

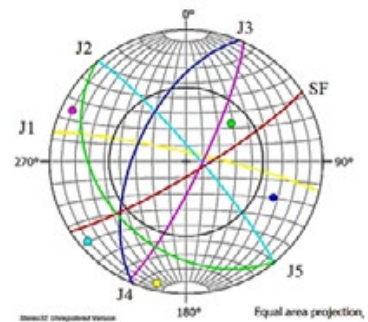

Figure 21: Kinematic analysis for slope GL1, Gunung Lang using friction angle of $43^{\circ}$. No mode of failure on this slope.

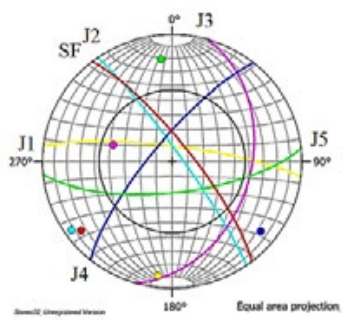

Figure 22: Kinematic analysis for slope GL2, Gunung Lang using friction angle of $43^{\circ}$. No mode of failure on this slope

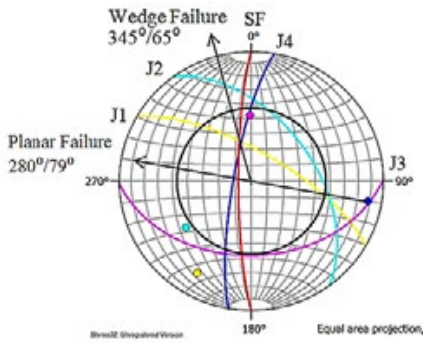

Figure 23: Kinematic analysis for slope GL3, Gunung Lang using friction angle of $43^{\circ}$. Fron the kinematic analysis, a planar and a wedge fallure were identified. The dip direction/dip angle for respective wedge and planar fallure were $345^{\circ} / 65^{\circ}$ and $280^{\circ} /$.

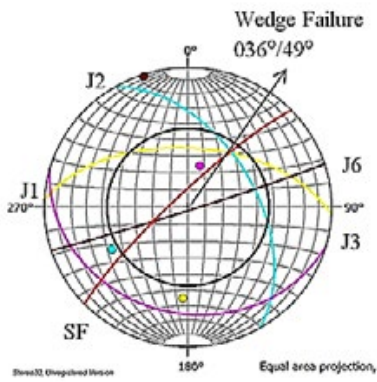

Figure 24: Kinematic analysis for slope GR1. Gunung Rapat using friction angle of $43^{\circ}$ From the kinematic analysis, a wedge failure was identified The dip direction/dip angle for the wedge failure was $036^{\circ} / 49^{\circ}$

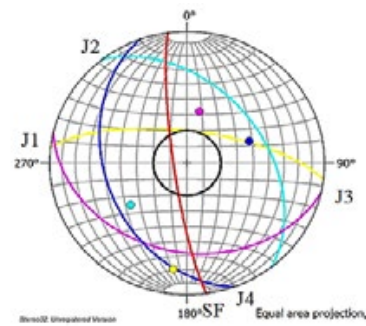

Figure 25 . Kinematic analysis for slope GR2, Gunung Rapat using friction angle of $70^{\circ}$. No mode of failure on this slope.

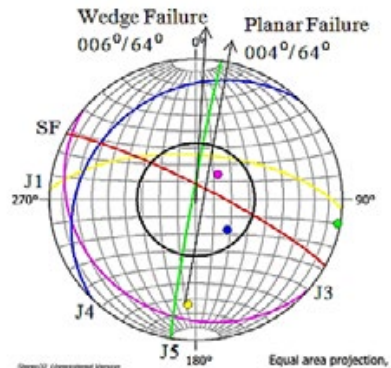

Figure 26. Kinematic analysis for slope GR3, Gunung Rapat using friction angle of $33^{\circ}$ From the kinematic analysis, a planar and a wedge failure were identified. The dip direction/dip angle for respective wedge and planar failure were $006^{\circ} / 64$ and $004^{\circ} / 64^{\circ}$

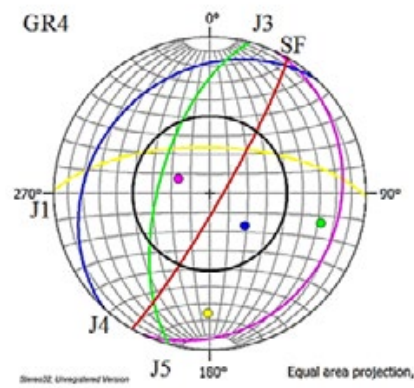

Figure 27: Kinematic analysis for slope GR4, Gunung Rapat using friction angle of $49^{\circ}$. No mode of failure on this slope.

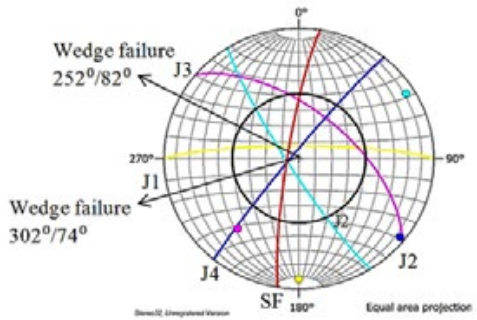

Figure 28: Kinematic analysis for slope QXL1. Qing Xing Ling using friction angle of $49^{\circ}$. From the kinematic analysis, two wedge failures were identified The dip direction/dip angle for the respective wedge fallures were $252^{\circ} / 82^{\circ}$ and $302^{\circ} / 74^{\circ}$.

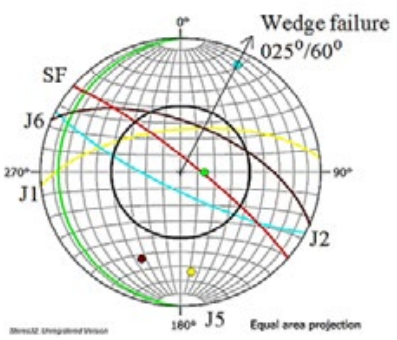

Figure 28: Kinematic analysis for slope QXI.2, Qing Xing Ling using friction angle of $49^{\circ}$. From the kinematic analysis, a wedge failure was identified. The dip direction dip angle for the wedge fallure was $0256^{\circ}, 60^{\circ}$.

Table 3: Summary of kinematic analysis for slopes GL1, GL2 and GL3, for Gunung Lang. Ipoh; GR1, GR2, GR3, GR4 and GR5, for Gununs Rapat. Ipoh; QXL1 and QX12, for Qing Xing Ling, Gunung Rapat, Ipoh.

\begin{tabular}{|c|c|c|c|}
\hline Slope & $\begin{array}{c}\text { Friction angle } \\
\phi\end{array}$ & $\begin{array}{l}\text { Joint Roughness } \\
\text { Coefficient } \\
\text { (JRC) }\end{array}$ & Failure Mode \\
\hline GL1 & 43 & 5 & No failure \\
\hline GL2 & 43 & 5 & No failure \\
\hline \multirow{2}{*}{ GL3 } & \multirow{2}{*}{43} & \multirow{2}{*}{5} & Wedge failure: $345^{\circ} / 65^{\circ}$ \\
\hline & & & Planar failure: $280^{\circ} / 79^{\circ}$ \\
\hline GRI & 43 & 5 & Wedge failure: $036^{\circ} / 49^{\circ}$ \\
\hline GR2 & 70 & 15 & No failure \\
\hline \multirow{2}{*}{ GR3 } & \multirow{2}{*}{33} & \multirow{2}{*}{9} & Wedge failure: $006^{\circ} / 64^{\circ}$ \\
\hline & & & Planar failure: $004^{\circ} / 64^{\circ}$ \\
\hline GR4 & 49 & 7 & No failure \\
\hline \multirow{2}{*}{ QXL1 } & \multirow{2}{*}{49} & \multirow{2}{*}{7} & Wedge falure: $252^{\circ} \% 2^{\circ}$ \\
\hline & & & Wedge failure: $302^{\circ} / 74^{\circ}$ \\
\hline QXL2 & 49 & 7 & Wedge failure: $025^{\circ} / 60^{\circ}$ \\
\hline
\end{tabular}




\section{CONCLUSION}

From the kinematic analysis assessment,a wedge failure was identified at on slope GL3, for Gunung Lang. The dip direction and dip angle of the wedge failureswas $345^{\circ} / 65^{\circ}$.There are no modes of failureson slope GL1 and GL2 for Gunung Lang. A wedge failure was identified onslope GR1 for Gunung Rapat with the dip direction and dip angle of $036^{\circ} / 49^{\circ}$. No modes of failure were identified on slope GR2 for Gunung Rapat. A wedge and planar failure were identified on slope GR3 for Gunung Rapat. The dip direction and dip angle for the respective wedge and planar failure were $006^{\circ} / 64^{\circ}$ and $004^{\circ} /$ $64^{\circ}$. No modes of failurewere identified on slope GR4 for Gunung Rapat. Two wedge failures were identified on slope QXL1 for Qing Xing Ling, while a wedge failure was identified on slope QXL2 for Qing Xing Ling. The dip direction and dip angle for the respective wedge failures were $252^{\circ} / 82^{\circ}$, $302^{\circ} / 74^{\circ}$ and $025^{\circ} / 60^{\circ}$.

Acknowledgement

This publication is based on work supported by the Government of Malaysia under grant Fundamental Research Grant Scheme FRGS/1/2016/STG08/ UTP/01/1, e-Science fund grant scheme 06-01-02-SF 1140, and GUP-2016024. The authors would also like to acknowledge the support of the staff and facilities at Geology Program and Faculty of Science and Technology, Universiti Kebangsaan Malaysia.

REFENCES

Abdul Ghani Rafek and Goh, T.L., 2012. Correlation of joint roughness coefficient (JRC) and peak friction angles of discontinuities of Malaysian Schists. Earth Science Research; 1(1):57-63

Abdul Ghani Rafek, Goh T. L., Askury A. Kadir, Chow, W. S., Choong, C. M., \& Norbert, S. 2015. Application of slope mass rating for quantification of rock slope stability: case studies of Kinta Limestone, Ipoh, Perak. Proceeding of International Conference on Slopes, Malaysia 2015 : 79-85.

Chow, W. S., \& Majid Sahat.1988. BatuRuntuh di Gunong Tunggal, Gopeng Perak. Geological Survey Report. Ipoh: Minerals \& Geoscience Department, Malaysia, 1/1988.

Foo, K. Y., (1983);ThePaleozoic Sedimentary Rocks of Peninsular MalaysiaStratigraphy and Correlation. Proceeding of the Workshop on Stratigraphic Correlation of Thailand and Malaysia,; 1: 1-19.

Ghani Rafek, A., Goh, T.L., Hariri Arifin, M. 2012. Korelasi pekali kekasaran kekar dengan sudut geseran puncak satah ketakselanjaran batuan Syis, Semenanjung Malaysia.Sains Malaysiana 41(3):293-297.

Ghani, R.A., Goh, T.L.,Hariri, A.M. and Baizura, Y.N. 2011.Field and Laboratory-based Approach for the Determination of Friction Angle of Geological Discontinuities of Malaysian Granites. Asean J. Sc. Technol. Dev. 28(2):151-155.

Goh, T.L., Abdul Ghani, R., \& Hariri, A. 2012b.Geomechanical Strength of Granites and Schists of Peninsular Malaysia. Sains Malaysiana 41(2):193198.

Goh, T.L., Ghani Rafek, A. \& Hariri Arifin, M. 2014a. Correlation of joint roughness coefficient with peak friction angles of discontinuity planes of granite, Peninsular Malaysia. SainsMalaysiana 43(5):751-756.

Goh, T.L., Abdul Ghani, R., Ailie, S.S., Norbert, S. and Lee K.E. 2014b.Empirical Correlation of Uniaxial Compressive Strength and Primary Wave Velocity of Malaysian Granites. Electronic Journal Geotechnical Engineering 19 (E) : 1063-1072.

Goh, T.L., Abdul Ghani, R., Ailie, S.S., Norbert, S., Lee K.E., and Azimah, H. 2015a.Empirical Correlation of Uniaxial Compressive Strength and Primary Wave Velocity of Malaysian Schists. Electronic Journal Geotechnical Engineering 20: 1801-1812.

Goh, T.L., Abdul Ghani, R., Ailie, S.S., Norbert, S., Azimah, H. and Lee K.E. 2015b.Correlation of Ultrasonic Velocity slowness with Uniaxial Compressive Strength of Schists in Malaysian. Electronic Journal Geotechnical Engineering 20: 12663-12670.
Ultrasonic Velocity Travel Time to Estimate Uniaxial Compressive Strength of Granite and Schist in Malaysia. Sains Malaysiana 45(2):185-193.

Hoek, E. and Bray, J. (1981) Rock Slope Engineering, 3rd edn, Inst. Mining and Metallurgy, London, UK.

Hutchison, C. S., \& Tan, N. K. (2009).Geology of Peninsular Malaysia. Kuala Lumpur: Geological Society of Malaysia.

ISRM (1978).Commission on standardization of laboratory and field tests. Suggested methods for the quantitative description of discontinuities in rock masses. Int. J. Rock Mech. min. Sci., 15, No.6, 319-368. Reprinted in Rock characterization and monitoring - ISRM suggested methods, E. T. Brown (eds.), 1981, 3-52, Oxford: Pergamon .

Lai, K. H. (1974). Rockfall Danger at the Southern End of Gunung Lang, Ipoh.Geological Survey Report. Ipoh: Minerals \& Geoscience Department, Malaysia.

Leman, M. S. (2013). Proposed Kinta Valley Geopark-utilizing Geological Resources for Environmental Quality Improvement and Society Well Being Enhancement.Keynote address.Proceeding of the National Geosience Conference.Kinta Riverfront Hotel and Suites, Ipoh, Malaysia.

Norbert, S., Michael, C., Mairead, d. Abdul Ghani, R. and Rodeano, R. 2015a. Time series assessment on landslide occurrences in an area undergoing development. Singapore Journal of Tropical Geography 36 : 98-111.

Norbert, S., Muhammad Fahmi, A.G., Goh, T.L, Abdul Ghani, R., Azimah, H., Rodeano, R. and Lee, K.E. 2015b. Assessment of rockfall potential of limestone hills in the Kinta Valley. Journal of Sustainability Science and Management 10(2) 24-34

Norbert, S., Rodeano, R., Abdul Ghani, R., Goh, T.L., Noran, N.N.A., Kamilia, S., Nightingle, L.M., Azimah, H. and Lee, K.E. 2016. Rock Mass Assessment using Geological Strength Index (GSI) along the Ranau-Tambunan Road, Sabah, Malaysia.Research Journal of Applied Sciences, Engineering and Technology 12(1): 108-115

Norbert, S., Rodeano, R., Nightingle, L.M., Juhari, M. A., Abdul Ghani, R., Goh, T.L. 2014. Lineaments And Their Association With Landslide Occurrences Along The Ranau-Tambunan Road, Sabah. Electronic Journal Geotechnical Engineering 19 (c) : 645-656.

Priest, S. D. \& Hudson, J.A. 1976.Discontinuity spacing in rock.Int. J. Rock Mech.

\section{Min Sci.And Geomech.Abst.,13 : 135-148}

Ruhr University Bochum. 2016. Steoreo 32. [http://www.ruhr-uni-bochum. de/hardrock/downloads.html]

Shu, Y. K., Lai, K. H. (1973). Rockfall Danger at Gunung Lang Rifle Range Road, Ipoh. Geological Survey Report. Ipoh: Minerals \& Geoscience Department, Malaysia.

Shu, Y. K., Lai, K. H. (1974). Rockfall at Gunung Cheroh, Ipoh. Geological Survey Report. Ipoh: Minerals \& Geoscience Department, Malaysia.

Shu, Y. K., Razak Y. A. (1984). Rockfall at Gunung Pondok Padang Rengas, Perak. Geological Survey Report. Ipoh: Minerals \& Geoscience Department, Malaysia. 